\title{
Charge-Transfer Cycloaddition of Homobenzvalene with Tetracyanoethylene
}

\author{
Eunkyoung Kim a, Manfred Christl ${ }^{b}$, and Jay K. Kochi *a \\ Department of Chemistry, University of Houston ", \\ University Park, Houston, Texas 77204-5641, U.S.A. \\ Institut für Organische Chemie der Universität Würzburg ${ }^{b}$, \\ Am Hubland, D-8700 Würzburg, F.R.G.
}

Received December 20, 1989

Key Words: Electron transfer, photochemical / Radical-ion pair / Photochemistry

The transient yellow color observed in the cycloaddition of homobenzvalene (HB) with tetracyanoethylene (TCNE) is associated with the charge-transfer complex [HB,TCNE]. The deliberate photoexcitation of [HB,TCNE] affords a mixture of charge-transfer cycloadducts $(1,2$, and 3$)$ that differs from that obtained in thermal cycloaddition. The relationship of $\left[\mathrm{HB}^{+}\right.$ $\mathrm{TCNE}^{-}$] radical-ion pair (as the critical reactive intermediate in charge-transfer cycloaddition) to the activation process for thermal cycloaddition is discussed.
The Diels-Alder cycloadditon of tetracyanoethylene (TCNE) to various anthracenes is visually characterized by transient colors with the vivid hues covering the entire visible spectrum attendant upon substituent changes on the aromatic donor $(\mathrm{Ar})^{1-3)}$. Spectrophotometric studies establish the colors to derive from weak $1: 1$ complexes that are initially formed upon the exposure of TCNE to arenes, i.e.

$$
\mathrm{TCNE}+\mathrm{Ar} \stackrel{\kappa}{\rightleftharpoons}[\mathrm{TCNE}, \mathrm{Ar}]
$$

with the formation constant $K$ typically less than $10^{27}$. As such, the spectral characterization of these transient molecular complexes by their intense electronic absorption in the visible region is in accord with Mulliken's prediction of the charge-transfer (CT) transition from the electron-rich aromatic donor ( $\mathrm{Ar}$ ) to the electron-poor acceptor (TCNE) ${ }^{4,5}$ ).

The close relationship of the CT excited state and the transition state of the thermal process can be deduced from the linear free energy correlation observed between the charge-transfer excitation energy $\left(h v_{C T}\right)$ of the [TCNE - Anthracene] complex and the secondorder rate constant $\left(\log k_{2}\right)$ for the Diels-Alder cycloaddition ${ }^{6)}$. Indeed, a related study ${ }^{7}$ of the $[2+4]$ cycloaddition of TCNE and diphenylbenzocyclobutene (DBC) recently established the chargetransfer activation to follow the same stereochemical course as that obtained by the thermal valence tautomerization of $\mathrm{DBC}$, as previously delineated by Huisgen, Quinkert, and co-workers ${ }^{8.9}$. However, the attempt to demonstrate the direct involvement of the [TCNE-Arene] complex in the Diels-Alder cycloaddition by CT activation was beset with experimental difficulties ${ }^{10}$. Thus, those anthracenes (with electron-withdrawing substituents) which could be examined photochemically afforded thermally labile (i.e. reversible) Diels-Alder adducts, whereas the other analogues yielded stable adducts but at thermal rates that were too fast to provide an unambiguous answer. Accordingly, we have focussed our attention in this study on the facile cycloaddition of TCNE to homobenzvalene ${ }^{(1)}$, when we learned of the fleeting yellow color ${ }^{\text {(2) }}$ that was suggestive of the CT complexes as transient intermediates of the type described above.

\section{Results}

\section{Charge-Transfer Complexes of Homobenzvalene and TCNE}

A colorless solution of homobenzvalene (HB) in dichloromethane immediately took on an orange-red color when
TCNE was added. The color was sufficiently persistent at $0^{\circ} \mathrm{C}$ to allow the absorption spectrum of the charge-transfer complex with $\lambda_{\max }=452 \mathrm{~nm}$ to be clearly resolved from the local bands of both homobenzvalene and TCNE (Figure 1). Owing to the very low solubility of TCNE in

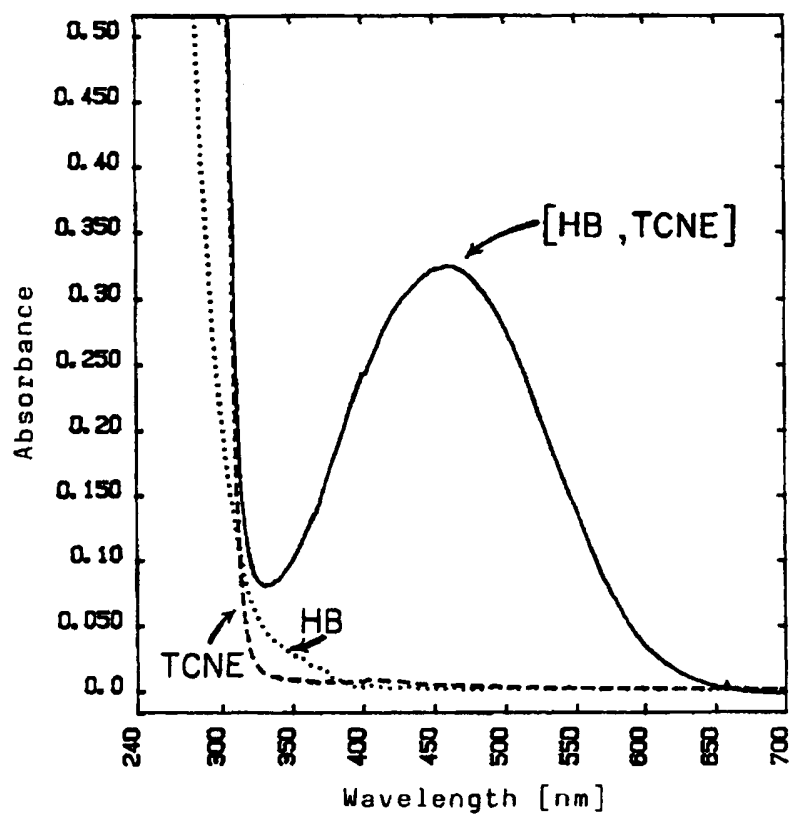

Figure 1. Charge-transfer spectrum of homobenzvalene $(0.065 \mathrm{M}$ and TCNE $(0.034 \mathrm{M})$ in dichloromethane at $0^{\circ} \mathrm{C}(\longrightarrow)$ in comparison with the absorption spectrum of the uncomplexed donor

$$
(\cdots \cdots) \text { and acceptor }(-\cdots \cdot) \text { at the same concentration }
$$

hexane, the charge-transfer spectrum was measured in this solvent with various amounts of homobenzvalene in excess. Under these conditions, the variation of the charge-transfer absorbance $A_{\mathrm{CT}}$ is given by the Benesi-Hildebrand relationship $^{13,14)}$ :

$$
\frac{[\mathrm{TCNE}]}{A_{\mathrm{CT}}}=\frac{1}{K \varepsilon_{\mathrm{CT}}} \frac{1}{[\mathrm{HB}]}+\frac{1}{\varepsilon_{\mathrm{CT}}}
$$


where $K$ is the formation constant and $\varepsilon_{C T}$ is the extinction coefficient of the $1: 1$ complex [HB,TCNE] at $\lambda_{\max }=430$ $\mathrm{nm}$. From the observed linear relationship of $A_{\mathrm{CT}}^{-1}$ as a function of the homobenzvalene concentration $[\mathrm{HB}]^{-1}$, a value of $K=10 \mathrm{M}^{-1}$ and $\varepsilon_{\mathrm{CT}}=190 \mathrm{M}^{-1} \mathrm{~cm}^{-1}$ was evaluated for the CT complex in hexane solution.

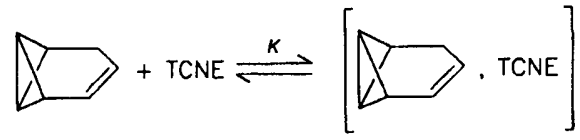

Such a magnitude of the formation constant of [HB,TCNE] placed it in the category of other weak complexes ${ }^{15}$. Moreover, like other weak complexes, the energy of the charge-transfer transition was not strongly dependent on the medium ${ }^{16)}$ as shown by the relatively invariant values of $\lambda_{C T}$ in Table 1, especially if solvents are considered in the order of increasing polarity: hexane, tetrahydrofuran, dichloromethane, and acetonitrile. In contrast, the persistence of the CT absorption was strongly dependent on the solvent polarity. In either hexane or THF, the red-orange color was intact for more than $10 \mathrm{~h}$ at $0^{\circ} \mathrm{C}$, but was only fleetingly observed in acetonitrile. Cooling the acetonitrile solution to $-40^{\circ} \mathrm{C}$ was required before the CT absorption could be made to persist unchanged for more than $4 \mathrm{~h}$.

Table 1. Charge-transfer spectrum of the homobenzvalene complex with TCNE

\begin{tabular}{|c|c|c|c|c|c|}
\hline $\begin{array}{l}\text { HB } \\
{[\mathrm{M}]}\end{array}$ & $\begin{array}{c}\text { TCNE } \\
{[\mathrm{M}]}\end{array}$ & Solvent & $\begin{array}{l}\text { Temp. } \\
\left.{ }^{\circ} \mathrm{C}\right]\end{array}$ & $\begin{array}{c}\lambda_{\mathrm{CT}} \\
{[\mathrm{nm}]}\end{array}$ & $\begin{array}{c}\tau^{8\}} \\
{[h]}\end{array}$ \\
\hline 0.029 & 0.0016 & Hexane & 0 & 440 & $>10$ \\
\hline 0.047 & 0.021 & THF & 0 & $440(\mathrm{sh})$ & $>10$ \\
\hline 0.33 & 0.13 & $\mathrm{CDCl}_{3}$ & 0 & 458 & 7 \\
\hline 0.045 & 0.037 & $\mathrm{CH}_{2} \mathrm{Cl}_{2}$ & 0 & 452 & 7 \\
\hline 0.045 & 0.037 & $\mathrm{CH}_{2} \mathrm{Cl}_{2}$ & 20 & 461 & $<0.2$ \\
\hline 0.072 & 0.060 & $\mathrm{CH}_{3} \mathrm{CN}$ & -40 & ca. 400 & 4 \\
\hline
\end{tabular}

a) Approximation for the persistence of the charge-transfer.

\section{Charge-1ransfer Cycloaddition of the Homobenzvalene with TCNE}

Irradiation of the mixture of homobenzvalene and TCNE was initially carried out in dichloromethane solution at $0^{\circ} \mathrm{C}$ owing to the persistence of the charge-transfer absorption band under these conditions (vide supra). In order to ensure the specific photoexcitation of only the [HB,TCNE] complex, the actinic output from a $1000-W$ mercury/xenon lamp was passed through a sharp cutoff filter that allowed the passage only of light with $\lambda>425 \mathrm{~nm}$. The inspection of Figure 1 shows that such light could only excite the chargetransfer band. Thus, in these studies there could be no ambiguity about either the adventitious local excitation of the uncomplexed HB donor (or TCNE acceptor) or the generation of intermediates other than those arising directly from the charge-transfer excitation of the [HB,TCNE] complex. The spectral changes accompanying the irradiation of the [HB,TCNE] complex at $0^{\circ} \mathrm{C}$ are shown in Figure 2 by the monotonic growth of a new absorption band at $\lambda_{\max } \approx 380$ $\mathrm{nm}$. Typically, the photoconversion was carried to $60 \%$, following the interruption of the irradiation after $7 \mathrm{~h}$ and immediate separation of the unreacted homobenzvalene by concentration of the photolysate in vacuo at $0^{\circ} \mathrm{C}$. The residual mixture of TCNE adducts was column-chromatographed on neutral alumina with a $2: 1(\mathrm{v} / \mathrm{v})$ mixture of hexane/ ether to afford three components. The first fraction yielded the yellow crystalline adduct tricyclo[4.3.0.0.0.7. $8,8,9,9$-tetracarbonitrile (1) in $33 \%$ yield. Indeed, the absorption spectrum of pure 1 with $\lambda_{\max }=389 \mathrm{~nm}\left(\varepsilon_{\max }=\right.$ $130 \mathrm{M}^{-1} \mathrm{~cm}^{-1}$ ) showed it to be largely responsible for the spectral change in Figure 2. The structure of 1 was established by X-ray crystallography, and the ORTEP diagram

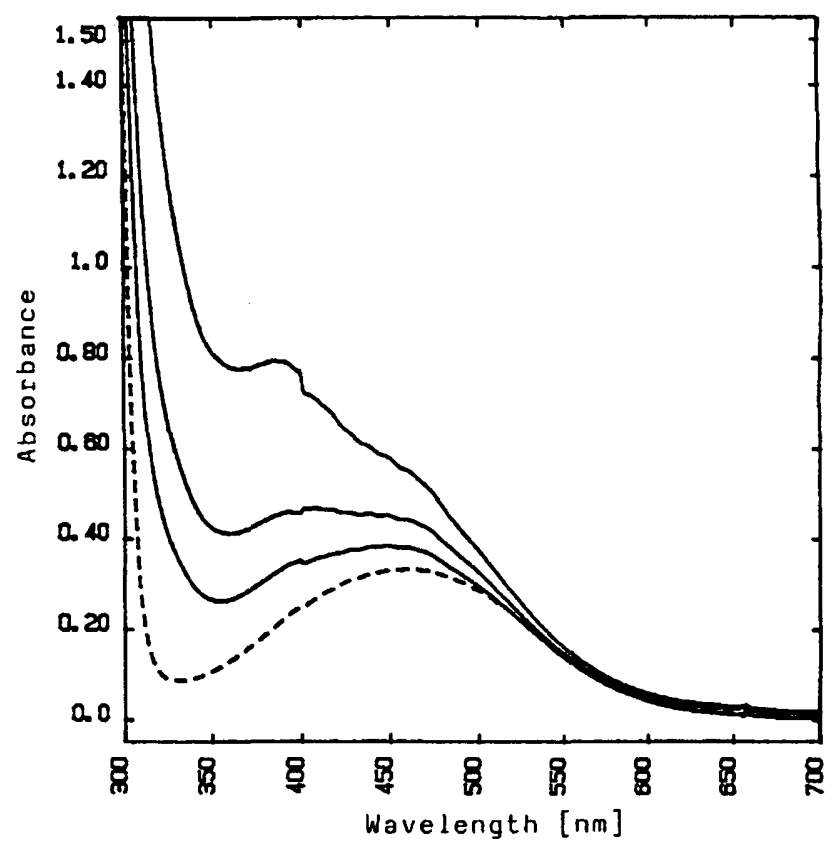

Figure 2. Spectral changes resulting from the photoexcitation of the CT band (-......) from $0.071 \mathrm{M}$ HB and $0.034 \mathrm{M}$ TCNE in dichloromethane at $0^{\circ} \mathrm{C}$ taken (bottom-to-top) after 1,2 , and $3 \mathrm{~h}$ irradiation at $\lambda>425 \mathrm{~nm}$

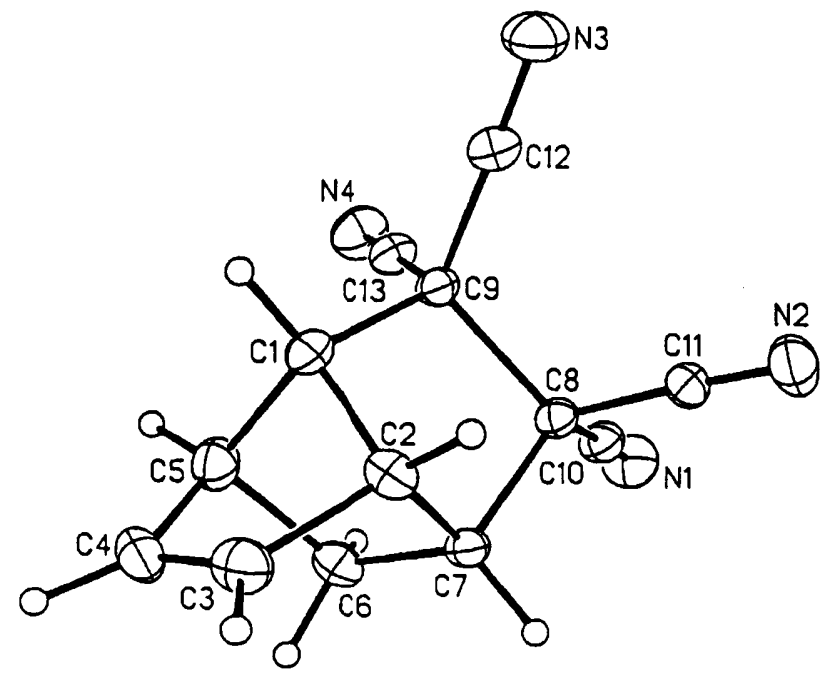

Figure 3. ORTF.P dialgram of the charge-transfer cycloadduct 1 
Table 2. Charge-transfer cycloaddition of homobenzvalene with $\mathrm{TCNE}^{\mathrm{a})}$

\begin{tabular}{|c|c|c|c|c|c|c|c|c|c|}
\hline$\underset{[\mathrm{mmol}]}{\mathrm{HB}}$ & $\begin{array}{c}\text { TCNE } \\
{[\mathrm{mmol}]}\end{array}$ & Solvent & $\begin{array}{l}\text { Temp. } \\
{\left[{ }^{\circ} \mathrm{C}\right]}\end{array}$ & $\begin{array}{l}\text { Time } \\
{[\mathrm{h}]}\end{array}$ & 1 & $\underset{2}{\text { Product }}[\mathrm{mmol}]$ & 3 & $\begin{array}{l}\text { Ratio } \\
1: 2: 3\end{array}$ & $\begin{array}{c}\text { Conversion } \\
(\%)\end{array}$ \\
\hline 0.75 & 0.14 & Hexane & 0 & 7 & 0.023 & 0.021 & 0.023 & $1.1: 1.0: 1.1$ & 47 \\
\hline 0.68 & 0.59 & THF & -50 & 10 & 0.034 & 0.015 & 0.020 & $1.7: 1.0: 0.8$ & 12 \\
\hline 0.42 & 0.28 & $\mathrm{CDCl}_{3}$ & -50 & 6 & 0.070 & 0.030 & 0.064 & $2.3: 1.0: 2.1$ & 59 \\
\hline 1.63 & 0.35 & $\mathrm{CH}_{2} \mathrm{Cl}_{2}$ & 0 & 7 & 0.120 & 0.044 & 0.059 & $2.5: 1.3: 1.0$ & 62 \\
\hline 0.50 & 0.38 & $\mathrm{CH}_{2} \mathrm{Cl}_{2}$ & -50 & 5 & 0.110 & 0.010 & 0.042 & $2.7: 1.0: 1.2$ & 43 \\
\hline 0.59 & 0.34 & $\mathrm{CH}_{3} \mathrm{CN}$ & -35 & 4 & 0.091 & 0.029 & 0.041 & $3.1: 1.0: 1.4$ & 61 \\
\hline
\end{tabular}

a) Irradiation with light $\lambda>315 \mathrm{~nm}$ in hexane, $\lambda>415 \mathrm{~nm}$ in $\mathrm{THF}$ or $\mathrm{CH}_{3} \mathrm{CN}$, and $\lambda>425 \mathrm{~nm}$ in $\mathrm{CDCl}_{3}$ or $\mathrm{CH}_{2} \mathrm{Cl}_{2}$.

is illustrated in Figure 3. The intermediate fraction yielded colorless crystals that were readily identified as tricyclo[3.2.2.0 $0^{2.4}$ ]non-8-ene-6,6,7,7-tetracarbonitrile (2) by direct comparison with an authentic sample prepared from the TCNE cycloaddition to cycloheptatriene ${ }^{17}$. The last chromatographic fraction, consisting of $\mathbf{2}$ admixed with the third component, could not be further separated. However, the ${ }^{1} \mathrm{H}-\mathrm{NMR}$ spectrum of 3 (showing its principal resonances in the narrow region between $\delta=1.8$ and 3.7) was clearly differentiated from the resolved AMX multiplets ${ }^{17}$ of the highly symmetric 2 . Importantly, the hyperfine splitting pattern in the ${ }^{1} \mathrm{H}-\mathrm{NMR}$ spectrum of 3 was strongly reminiscent of those previously found in the cycloadducts of $N$-phenyltriazolinedione (PTAD) with homobenzvalene ${ }^{18,19)}$ and its methyl derivative ${ }^{20)}$. The invocation of the same skeletal framework for 3 led to the assignment tetracyclo$\left[4.3 .0 .0 . .^{2,4} 0^{3,9}\right]$ nonane-7,7,8,8-tetracarbonitrile, the connectivities of which were unambiguously established by the twodimensional COSY spectrum (see Experimental). It is noteworthy that the repetition of the experiment at lower temperatures $\left(-50^{\circ} \mathrm{C}\right)$ led to no significant change in either the photo-conversion or the distribution of the isomeric products (Table 2).

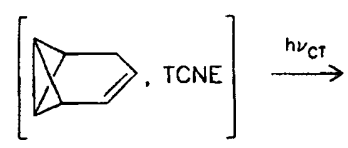

CT complex

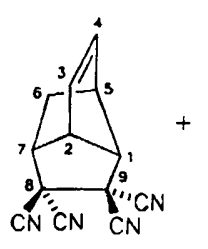

1

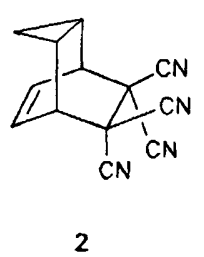

2
The formation of the isomeric TCNE cycloadducts with homobenzvalene by irradiation according to eq. (4) is hereafter referred to as charge-transfer cycloaddition, arising as it does by the direct photoexcitation of the [HB,TCNE] complex. The course of the CT cycloaddition could be followed directly by observing the changes in the ${ }^{1} \mathrm{H}-\mathrm{NMR}$ spectrum during the irradiation of homobenzvalene and TCNE in [D]chloroform. Figure 4 shows the monotonic disappearance of homobenzvalene (and appearance of the principal adduct 1), uncomplicated by the formation of any valence isomer as possible intermediates. Thus, each of the unique TCNE adducts in eq. (4) resulted directly from the CT excited state and not from some subsequent photoisomerization since neither 1,2 , nor 3 were capable of absorbing the incident light. Furthermore, the control experiments with the principal thermal adducts 2 and $\mathbf{4}$ (vide infra) showed that they were quantitatively recovered intact when solutions containing TCNE were irradiated under the conditions of the charge-transfer cycloaddition.

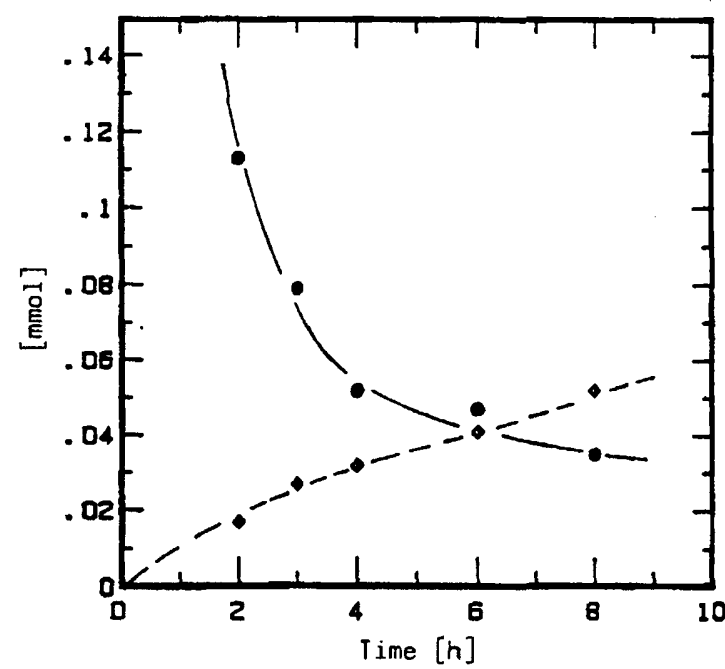

Figure 4. Monotonic disappearance of homobenzvalene $(\bullet)$ and the appearance of the CT cycloadduct $1(\diamond)$ during the irradiation of [HB,TCNE] in chloroform at $0^{\circ} \mathrm{C}$

The CT cycloaddition of homobenzvalene and TCNE in acetonitrile was carried out at $-35^{\circ} \mathrm{C}$ in order to obviate any complication from the thermal process in the more polar solvent. Although the photochemical conversion under these conditions was similar to that in dichloromethane at about the same temperature (see Table 2), the photolysate took on a distinct brown coloration. Inspection of the absorption spectra in Figure 5 shows the growth of the characteristic spectrum of tetracyanoethylene anion radical (TCNE-) that was readily identified by the diagnostic spacing of $550 \mathrm{~cm}^{-1}$ 
between vibronic energy levels ${ }^{21)}$. Calibration relative to that of an authentic salt ${ }^{22)}\left(\varepsilon_{460}=1480 \mathrm{M}^{-1} \mathrm{~cm}^{-1}\right.$, see Figure 5 inset) indicated the presence of roughly $1 \%$ tetracyanoethylene anion radical. Otherwise, the CT cycloaddition in acetonitrile was not significantly distinguished from that in dichloromethane.

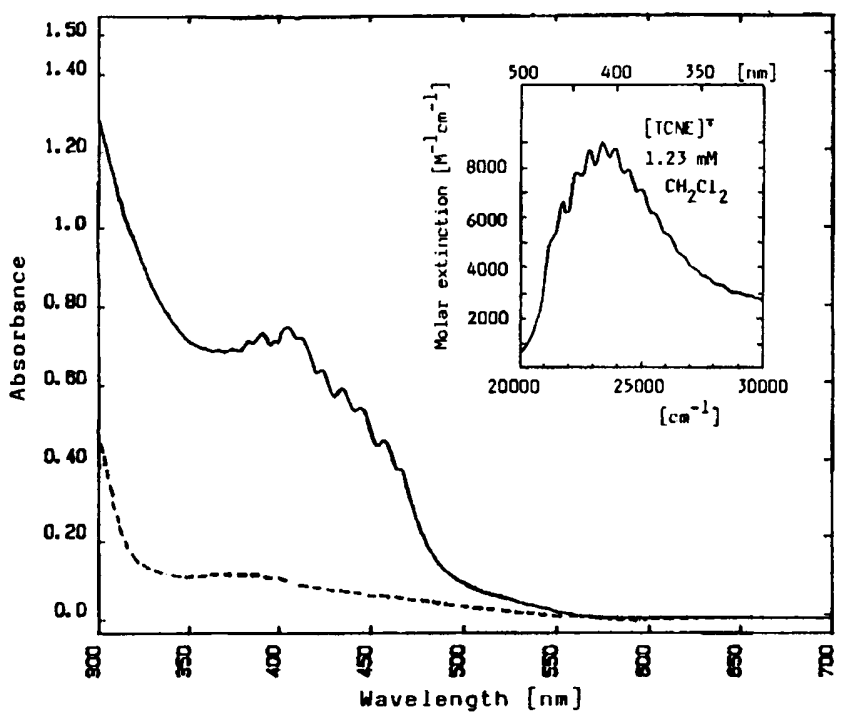

Figure 5. The charge-transfer spectrum from $0.087 \mathrm{M} \mathrm{HB}$ and 0.029 $M$ TCNE in acetronitrile at $-40^{\circ} \mathrm{C}(-\cdots-)^{---)}$and the absorption spectrum after irradiation for $40 \mathrm{~min}$ (-); the inset shows the absorption spectrum of TCNE- from ref. ${ }^{21)}$

The relative amounts of the CT cycloadducts 1,2 , and 3 were largely unaffected by changes in the medium. In particular, increases in solvent polarity ${ }^{24)}$ from hexane, tetrahydrofuran, dichloromethane, and acetonitrile led to only a minor increase in the importance of isomer 1 . Whereas the cycioadduct 2 appeared to follow a somewhat opposed trend, no clear-cut solvent dependency was observed in the formation of adduct 3. The results in Table 2 thus indicate that the variation in product distribution with solvent changes was, at most, quite minor.

\section{Thermal Cycloadditon of Homobenzvalene with TCNE}

In order to calibrate the charge-transfer cycloaddition of homobenzvalene and TCNE, especially with regard to medium effects, the red-orange solution was allowed to stand at room temperature without deliberate irradiation. The ensuing dark thermal reaction was followed spectrally by measuring the decrease in the CT absorbance. The changes in the CT absorption spectum in Figure 6 were accompanied by an increasing absorbance in the spectral region between $\lambda=320$ and $400 \mathrm{~nm}$. Indeed, the workup of the reaction mixture yielded the thermal TCNE adduct tricyclo[3.3.1.0.8. $]$ non-6-ene-3,3,4,4-tetracarbonitrile ${ }^{11)}$ (4) that was responsible for this spectral feature, owing to its yellow color and low-energy tail absorption. The additional pair of thermal cycloadducts 5 and 2 shown in eq. (5) were formed in amounts (Table 3) comparable to those originally reported by Christl and co-workers ${ }^{11}$. The structural characterization of the thermal cycloadducts in eq. (5) ${ }^{11}$ includes only the isomer 2 in common with the charge-transfer cycloadducts in eq. (4). The thermal cycloaddition of homobenzvalene with TCNE also differed from the CT process in its response to changes in the medium - with respect to both the distribution of isomeric products ${ }^{19)}$ and the rate of cycloadditon. Thus, the change in solvent polarity from hydrocarbon (benzene, hexane), tetrahydrofuran, dichloromethane to acetonitrile led to a progressive change from 2 as the sole thermal cycloadduct in the nonpolar solvent to 4 as the principal (ca. $70 \%$ ) isomer in the most polar solvent. Although the kinetics of the thermal cycloaddition were not examined, the rate differences were so large as to be unmistakable. For example, the thermal cycloaddition in either tetrahydrofuran or dichloromethane at $20^{\circ} \mathrm{C}$ required more than 6 days to attain ca. $50 \%$ conversion. By contrast, roughly the same occurred in acetonitrile in $15 \mathrm{~h}^{25}$.
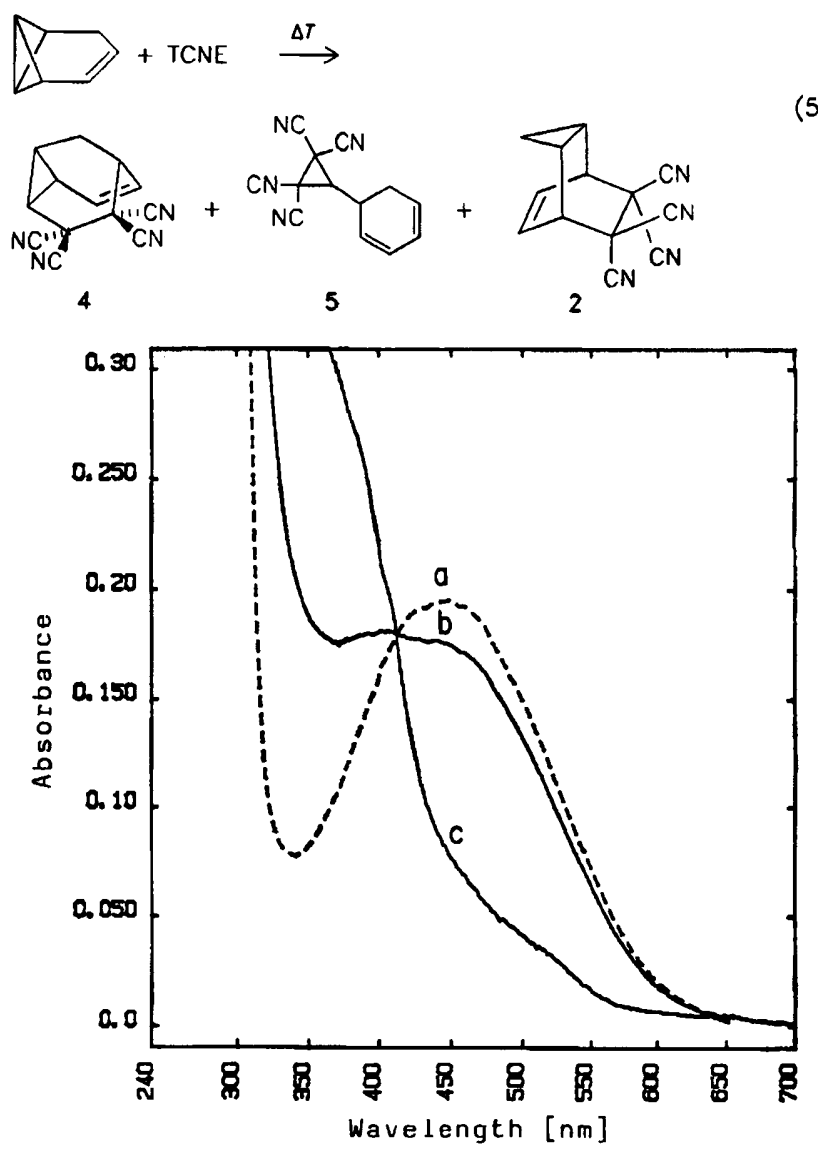

Figure 6. Spectral changes during the thermal cycloaddition of $0.045 \mathrm{M} \mathrm{HB}$ and $0.037 \mathrm{M}$ TCNE in dichloromethane at $25^{\circ} \mathrm{C}$ after (a) 0 , (b) 4 , and (c) $50 \mathrm{~h}$

\section{Discussion}

The cycloaddition of homobenzvalene (HB) with TCNE presents a unique opportunity to examine the thermal and charge-transfer activation of a pericyclic process simultaneously in a single system.

\section{Mechanism of Charge-Transfer Cycloaddition}

The charge-transfer activation of TCNE cycloaddition to homobenzvalene is a nonadiabatic process that must pro- 
Table 3. Thermal reaction of homobenzvalene with $\mathrm{TCNE}^{\text {() }}$

\begin{tabular}{|c|c|c|c|c|c|c|c|c|}
\hline$\underset{[\mathrm{mmol}]}{\mathrm{HB}}$ & $\begin{array}{c}\text { TCNE } \\
{[\mathrm{mmol}]}\end{array}$ & Solvent & $\begin{array}{c}\text { Time } \\
\text { [d] }\end{array}$ & 4 & $\underset{5}{\text { Product }}[\mathrm{mmol}]$ & 2 & $\begin{array}{l}\text { Ratio } \\
4: 5: 2\end{array}$ & $\begin{array}{c}\text { Conversion } \\
(\%)\end{array}$ \\
\hline 0.42 & 0.10 & THF & 7.0 & 0.023 & 0.008 & 0.020 & $2.8: 1.0: 2.6$ & 51 \\
\hline 0.92 & 0.33 & $\mathrm{CHCl}_{3}$ & 3.0 & 0.011 & 0.013 & 0.050 & $1.0: 1.2: 4.5$ & 22 \\
\hline 1.46 & 0.46 & $\mathrm{CH}_{2} \mathrm{Cl}_{2}$ & 7.0 & 0.140 & 0.060 & 0.070 & $2.3: 1.0: 1.2$ & 59 \\
\hline 0.43 & 0.32 & $\mathrm{CH}_{3} \mathrm{CN}$ & 0.6 & 0.067 & 0.016 & 0.014 & $4.4: 1.2: 1.0$ & 30 \\
\hline
\end{tabular}

at room temperature in the dark.

ceed directly from the vertical excitation of the [HB,TCNE] complex in Figure 1. For the latter, we have demonstrated how time-resolved picosesond spectroscopy can be used to define the photophysical and photochemical events associated with the charge-transfer excitation of the arene complexes with TCNE in eq. (1) to the ion-pair excited state ${ }^{26,27)}$. As applied to the homobenzvalene donor, the relevant chargetransfer excitation corresponds to eq. (6).

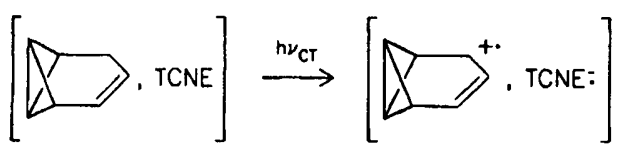

The electron transfer from homobenzvalene to TCNE in eq. (6) effectively occurs with the absorption of the excitation photon $\left(h v_{(T)}\right.$ in accord with the Mulliken theory applicable to weak complexes ${ }^{2 x}$. Accordingly, the ion radicals $\mathrm{HB}^{+}$ and TCNE- are born from the precursor complex as an intimate contact ion pair (CIP) since the photochemical time scale of $<30$ ps obviates significant competition from diffusional processes ${ }^{29}$. The seminal role of the ion pair $\left[\mathrm{HB}+\mathrm{TCNE}^{-}\right]$as the obligatory intermediate from the photoexcitation of the weak ground state complex ${ }^{30}$ [HB,TCNE] must therefore be included in any mechanistic formulation of CT cycloaddition by taking particular cognizance of how it decays. Most important is the competition from the return to the ground state by back electron transfer (bet) with a first-order rate constant that is estimated to be $k_{\text {bet }}>10^{10} \mathrm{~s}^{-1}$ from the redox potentials ${ }^{31,32)}$. Such a magnitude of $k_{\text {bet }}$ generally restricts the CT photoactivation of the TCNE complex to an ion pair with a lifetime of less than $10^{2} \mathrm{ps}$, that is usually attainable only by unimolecular fragmentation, rearrangements, etc. of the cation-radical moiety ${ }^{33}$. It therefore follows that the photoefficiency of the CT cycloaddition as presented in Table 2 arises from the structural alteration of $\mathrm{HB}^{ \pm}$with a rate constant $k_{2}>10^{10}$ $\mathrm{s}^{-1}$ to obviate significant competition from back electron transfer. Indeed, the cation radicals of strained hydrocarbons such as homobenzvalene are known to be highly susceptible to various types of ring-opening transformations ${ }^{34-36}$. Accordingly, we propose that spontaneous isomerization of $\mathrm{HB}+$ to the three cation radicals presented as $1 \div, 2 \div$, and $3 \div$ in Scheme $1^{37}$ represents the most economical formulation for the origin of the isomeric CT cycloadducts. Whether the subsequent annihilation of each of these cation radicals (i.e., $1 \pm, 2 \pm$, and $3 \div$ ) with the acceptor moiety $\mathrm{TCNE}^{-}$, e. g. eq. (7), proceeds in a concerted or stepwise manner to afford the CT cycloadducts 1,2 , and 3 , respectively, is not indicated by the results on hand. However, we hasten to add that the insensitivity of the product distribution among the isomeric cycloadducts 1,2 , and 3 to the solvent variation in Table 2 is best accommodated by a complete isomerization of $\mathrm{HB}^{ \pm}$(as in Scheme 1) prior to reaction with $\mathrm{TCNE}^{-}$. Indeed, the contact ion pair (CIP) initially formed in a highly nonpolar medium such as hexane is constrained to undergo annihilation directly within the solvent cage ${ }^{38}$, whereas polar solvents such as acetonitrile promote ionic dissociation to solvent-separated ion pairs (SSIP) prior to annihilation ${ }^{39}$. [Note that the latter is supported by the spectral observation of small but discrete amounts of TCNE- (Figure 5) only in the polar medium of acetonitrile ${ }^{40}$. .] Since the time scales for the annihilation of such disparate ion pairs differ by several orders of magnitude ${ }^{41}$, we conclude that the isomerization of $\mathrm{HB}$. must be complete at the CIP stage. Alternative formulations such as that involving the competition among zwitterionic intermediates ${ }^{42)}$ are expected to lead to different distributions among the isomeric cycloadducts 1,2 , and 3 as the polarity of the solvent is varied in the charge-transfer cycloaddition.

Scheme 1. Rearrangements of $\mathrm{HB}+$ to the isomeric cation radicals $1 \pm .2 \pm$, and $3 \div$ according to ref. $^{377}$
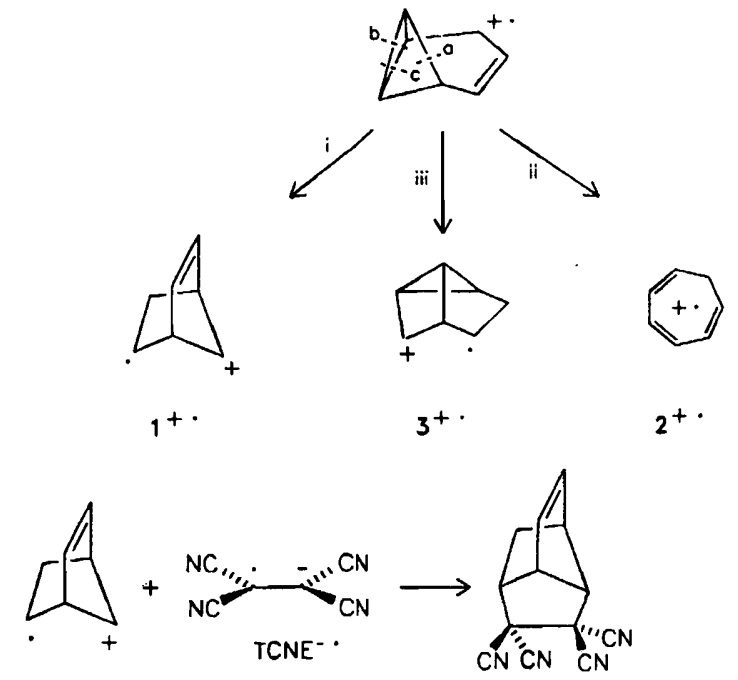

Comments on the Thermal Cycloaddition of Homobenzvalene with TCNE

The thermal cycloaddition of homobenzvalene with TCNE is an adiabatic process in which the transition state(s) is (are) 
attained by the collapse of the homobenzvalene donor with the tetracyanoethylene acceptor to afford the isomeric adducts 2,4 , and $5^{43}$. Unlike the mechanistic situation for charge-transfer cycloaddition, the intervention of reactive intermediates in the thermal cycloaddition is difficult to establish by direct methods. Thus, any reactive intermediate will not be formed in sufficient concentration to observe in a thermal process since its rate of further reaction will always be faster than its rate of production ${ }^{45}$ ). As a result, the mechanistic pathway for the thermal cycloaddition of homobenzvalene with TCNE must be deduced by indirect means, for example, by comparison with the CT cycloaddition. If so, Scheme $2^{46)}$ presents the alternative isomerizations of $\mathrm{HB} \pm$ to the isomeric cation radicals $2 \pm, 4 \pm$, and $5 \pm$ that are directly related to the thermal cycloadducts 2,4 , and 5 , respectively. However, the cation radical 5t (with both cationic charge and electron residing on the same methine center) is unlikely to arise from the rearrangement of $\mathrm{HB}^{+}$. Furthermore, the cation radicals $2 \div$ and $4 \div$ could arise from the rearrangement of $\mathrm{HB}^{+}$by bond fragmentation, but they cannot both be involved in thermal cycloaddition since $2 \pm$ is rapidly equilibrated with $1 \pm$ and $3 \pm$, as described above. Since the complexion of products in eq. (5) is quite distinct from that obtained in the CT cycloaddition [eq. (4)], we conclude that the homobenzvalene cation radical of the type presented in Scheme 1 certainly cannot be involved in the thermal process. Accordingly, the electrophilic attack at the 1-position of homobenzvalene by TCNE to generate zwitterionic intermediates as described by Christl and coworkers ${ }^{19}$, is a viable alternative for the production of the thermal cycloadducts 2,4 , and 5 . Such divergent pathways for thermal and charge-transfer cycloadditions provide a compelling mechanistic basis for the strong difference observed in their sensitivity to solvent variation that is otherwise difficult to reconcile ${ }^{47 ?}$.

Scheme 2. Hypothetical rearrangements of $\mathrm{HBt}$ to the putative cation radicals $2 !, 4 !$ and $5 !$ according to ref. ${ }^{+4 !}$

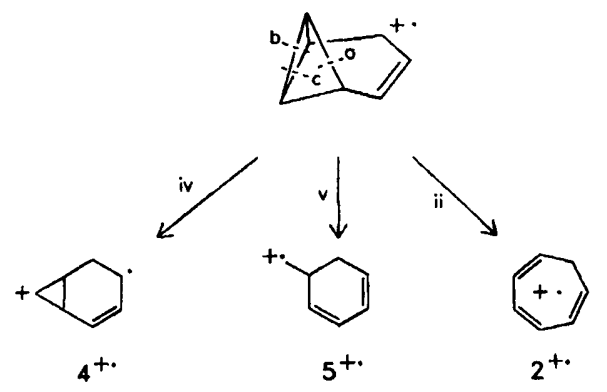

The common appearance of the cycloadduct 2 as an important component in both charge-transfer and thermal cycloaddition indicates that these activation processes are strongly coupled. Indeed, the photoelectron spectrum of homobenzvalene reveals at least two sites of potential reactivity centered at either the Walsh-type $a_{1}$ orbital of the strained bicyclobutane moiety [HOMO, $8.82 \mathrm{eV}]$ or the $\pi\left(b_{2}\right)$ orbital of the double bond [SHOMO, $9.20 \mathrm{eV}]^{48,49}$. Thus, in thermal cycloaddition, the electrophilic attack of TCNE at the frontier orbital ${ }^{50)}$ accords with the reactivity of ho- mobenzvalene centered about the strained edge $(\sigma)$ bond. However, CT cycloaddition proceeds by the vertical excitation of the [HB,TCNE] complex, and the reactivity is likely to be centered about the $\mathrm{C}=\mathrm{C}$ bond owing to the location of TCNE to optimize the $\pi-\pi^{*}$ interaction $^{51}$. In other words, the two processes are energetically separated by the HOMO-SHOMO gap in homobenzvalene. Since this gap is relatively small (ca. $0.4 \mathrm{eV})^{48}$, they can be competitive. By contrast, the HOMO-SHOMO gap in the homologue benzvalene is significantly larger $(1.2 \mathrm{eV})^{52}$, and the related comparison of the pathways for thermal ${ }^{53}$ and charge-transfer cycloadditions would be informative. In the meantime, the direct involvement of donor-acceptor complexes by the $\mathrm{CT}$ activation of the Diels-Alder and related cycloadditions remains a viable question.

We thank J. D. Korp for crystallographic assistance and the $\mathrm{Na}$ tional Science Foundation and $R$. A. Welch Foundation for financial support. J. K. K. also thanks the Alexander von Humboldt Foundation for a U.S. Senior Scientist award.

\section{Experimental}

Materials: Homobenzvalene (prepared from benzvalene ${ }^{500}$ was distilled in vacuo $\left(20^{\circ} \mathrm{C} / 3\right.$ Torr $)$ prior to use. Tetracyanoethylene (Aldrich) was sublimed $\left(80^{\circ} \mathrm{C} / 20\right.$ Torr) twice prior to use. Cycloheptatriene (Aldrich) was used without further purification. Solvents were purified as follows: Acetonitrile (HPLC grade, Fisher) was initially stirred with $\mathrm{KMnO}_{4}$ for $12 \mathrm{~h}$, and the mixture was heated to reflux for an additional hour. After filtration, the colorless liquid was treated with diethylenetriamine, and the mixture was refiltered. Acetonitrile was finally refractionated from $\mathrm{P}_{2} \mathrm{O}_{5}$ under an argon atmosphere. Dichloromethane (J. T. Baker) was initially stirred with conc. sulfuric acid. The separated layer was neutralized and dried with anhydrous $\mathrm{Na}_{2} \mathrm{CO}_{3}$. It was finally distilled from anhydrous $\mathrm{P}_{2} \mathrm{O}_{5}$ under an argon atmosphere. Tetrahydrofuran (Fisher) was stirred with $\mathrm{LiAlH}_{4}$ for $24 \mathrm{~h}$ and then fractionally distilled under an argon atmosphere. Hexane (J. T. Baker) was fractionally distilled from sodium under an argon atmosphere. Chloroform (J. T. Baker) and [D]chloroform (Aldrich) were distilled from powdered type $4 \AA$ molecular sieves (Aldrich).

Instrumentation: UV-VIS: Hewlett-Packard 8450 diode-array spectrometer with $2 \mathrm{~cm}^{-1}$ resolution. $-{ }^{1} \mathrm{H}$ and ${ }^{13} \mathrm{C} \mathrm{NMR}$ : JEOL FX 90Q, General Electric QE 300 FT-NMR, referenced relative to internal TMS. The two-dimensional COSY spectrum ${ }^{34}$ ) was recorded with the standard pulse sequence $\left(90^{\circ}-t_{1}-90^{\circ}-t_{2}\right)$ with a GE/ Nicolet NT-300 wide-bore NMR spectrometer with a $293 \mathrm{C}$ pulse programmer and a 1180 e computer. - IR: Nicolet 10DX FT. GC: Hewlett-Packard 5790 A chromatograph with 12.5 -m SE 30 capillary column. - GC MS: Hewlett-Packard 5890 chromatograph, interfaced to an HP-5970 mass spectrometer (EI, $70 \mathrm{eV}$ ). The light source for all irradiations consisted of a focussed beam from either an Optometric (No. XBO 450) 450-W xenon lamp or a Hanovia (No. 977-B1) 1000-W high-pressure mercury/xenon lamp. Glass sharp-cutoff filters (Corning) were used to eliminate light with wavelength less than that of the CT bands. The temperature was maintained during the irradiation with the aid of either ice-water $\left(0^{\circ} \mathrm{C}\right)$ or dry ice-acetone mixtures $\left(-30\right.$ to $\left.-78^{\circ} \mathrm{C}\right)$ contained in an unsilvered Dewar flask.

Charge-Transfer Absorption Spectra of the Homobenzvalene Complex with Tetracyanoethylene: All operations were performed under an argon atmosphere using Teflon-topped UV cells equipped with a 
side arm. Homobenzvalene ( $0.13 \mathrm{mmol} ; 0.042 \mathrm{M})$ was added to the UV cell charged with $3 \mathrm{ml}$ of dichloromethane, and the resulting colorless solution was cooled to $0^{\circ} \mathrm{C}$ using an ice-water bath. To the above solution $7.3 \times 10^{-3} \mathrm{mmol}(0.0025 \mathrm{M})$ of TCNE was added. Successive addition of preweighed amounts $(0.0065 \mathrm{M}, 0.044 \mathrm{M})$ of TCNE to the solution was followed by thorough mixing to afford reddish orange solutions $\left(\lambda_{\max }=452 \mathrm{~nm}\right)$ at $0^{\circ} \mathrm{C}$. The electronic spectra of the solution of homobenzvalene $(0.20 \mathrm{M})$ and TCNE $(0.11 \mathrm{M})$ in $3 \mathrm{ml}$ of acetonitrile was measured at $-40^{\circ} \mathrm{C}$. Spectra of individual components were measured at $25^{\circ} \mathrm{C}$. Since TCNE was slightly soluble in hexane, the slurry consisting of $18 \mathrm{mg}(0.14 \mathrm{mmol})$ of TCNE in $85 \mathrm{ml}$ of hexane was stirred vigorously for $2 \mathrm{~h}$ at $25^{\circ} \mathrm{C}$. The resultant colorless solution containing negligible amounts of undissolved TCNE $(<1 \mathrm{mg}$ ) was transferred to the UV cell, and successive amounts of preweighed homobenzvalene $(0.040 \mathrm{M}$ $0.19 \mathrm{M}, 0.23 \mathrm{M}, 0.26 \mathrm{M}, 0.30 \mathrm{M})$ were added to the solution of TCNE $(0.0016 \mathrm{M}, 3.1 \mathrm{ml})$. The solution of $0.10 \mathrm{mmol}(0.020 \mathrm{M})$ of TCNE in $5 \mathrm{ml}$ of THF was yellow, and a strong absorption below $400 \mathrm{~nm}$ was observed in the UV spectra even in the absence of homobenzvalene. The addition of $0.42 \mathrm{mmol}(0.084 \mathrm{M})$ of $\mathrm{HB}$ resulted in the absorbance increase at the long energy tail from 400 to $600 \mathrm{~nm}$ at $0^{\circ} \mathrm{C}$. The electronic absorption spectra of $\mathrm{HB}(0.67 \mathrm{mmol} ; 0.33 \mathrm{M})$ with TCNE $(0.25 \mathrm{mmol}$; ca. $0.33 \mathrm{M})$ in $\mathrm{CDCl}_{3}$ were measured in a $1-\mathrm{cm}$ diameter NMR tube at $0^{\circ} \mathrm{C}$ to yield the resolved CT band at $\lambda=458 \mathrm{~nm}$.

Charge-Transfer Cycloadditon of Homobenzvalene with TCNE: The red-orange solution of $150 \mathrm{mg}(1.63 \mathrm{mmol})$ of homobenzvalene with $45 \mathrm{mg}$ of TCNE in $10 \mathrm{ml}$ of dichloromethane was irradiated at $0^{\circ} \mathrm{C}$ with the output from a $1-\mathrm{kW}$ high-pressure mercury/xenon lamp which was passed through a Corning sharp-cutoff filter $(\lambda>425 \mathrm{~nm})$. After $4 \mathrm{~h}$, the yellow-brown solution was concentrated in vacuo at $0^{\circ} \mathrm{C}$ to afford $55 \mathrm{mg}$ of yellow-brown solid. The crude mixture was column-chromatographed on neutral alumina with a mixture of hexane and ether $(2: 1 ; \mathrm{v} / \mathrm{v})$ to give $26 \mathrm{mg}(0.12$ mmol, $33 \%)$ of 1 in the initial fraction, $8 \mathrm{mg}(0.036 \mathrm{mmol})$ of compound 2 in the intermediate fraction, and $15 \mathrm{mg}$ of a colorless mixture of 2 and 3 (1:7 by ${ }^{1} \mathrm{H}-\mathrm{NMR}$ integration) in the final fractions. The thermal cycloadduct 4 was observed ( ${ }^{1} \mathrm{H}$ NMR) in the last fraction, but the amount was $<0.01 \mathrm{mmol}(3 \%)$. Photolysis of the slurry of $46 \mathrm{mg}(0.50 \mathrm{mmol})$ of homobenzvalene with $49 \mathrm{mg}$ $(0.38 \mathrm{mmol})$ of TCNE in $4 \mathrm{ml}$ of dichloromethane was carried out at -60 to $-50^{\circ} \mathrm{C}$ with the $425-\mathrm{nm}$ cutoff filter. After $5 \mathrm{~h}$ the undissolved TCNE was removed ( $26 \mathrm{mg}, 0.20 \mathrm{mmol}$ ), and the volatile material was evaporated in vacuo. The orange solid was columnchromatographed to give $24 \mathrm{mg}(0.11 \mathrm{mmol})$ of 1 and $12 \mathrm{mg}$ of a $3: 1$ mixture of 3 and 2. Photoreaction of the orange solution of 54 $\mathrm{mg}(0.59 \mathrm{mmol})$ of $\mathrm{HB}$ with $43 \mathrm{mg}(0.34 \mathrm{mmol})$ of TCNE in $3 \mathrm{ml}$ of $\mathrm{CH}_{3} \mathrm{CN}$ was carried at -35 to $-40^{\circ} \mathrm{C}$ with the 415 -nm cutoff filter. After $4 \mathrm{~h}$, volatile material was evaporated in vacuo. The resultant yellow-brown solid was column-chromatographed on neutral alumina with a mixture of hexane and ether $(2: 1 ; \mathrm{v} / \mathrm{v})$ to give $20 \mathrm{mg}$ of $1(0.090 \mathrm{mmol})$ and a mixture of 2 and $3\left(1.4: 1.0\right.$ by ${ }^{1} \mathrm{H}-\mathrm{NMR}$ integration). The photoreaction of $63 \mathrm{mg}(0.68 \mathrm{mmol})$ of $\mathrm{HB}$ with $75 \mathrm{mg}(0.59 \mathrm{mmol})$ of TCNE in $8 \mathrm{ml}$ of THF was carried at -60 to $-50^{\circ} \mathrm{C}$ with the $415-\mathrm{nm}$ cutoff filter. After $10 \mathrm{~h}$, solvent and $\mathrm{HB}$ were evaporated in vacuo. The residue was column-chromatographed on neutral alumina with a mixture of hexane and ether to give $7.4 \mathrm{mg}(0.034 \mathrm{mmol})$ of 1 and a mixture of 3 and 2 (1.3:1.0 by ${ }^{1} \mathrm{H}-\mathrm{NMR}$ integration). The red-orange solution of $39 \mathrm{mg}(0.42$ mmol) with $36 \mathrm{mg}(0.28 \mathrm{mmol})$ of TCNE in $3.5 \mathrm{ml}$ of $\mathrm{CDCl}_{3}$ was irradiated at -60 to $-50^{\circ} \mathrm{C}$ with the $425-\mathrm{nm}$ cutoff filter. After $6 \mathrm{~h}, 5.4 \mathrm{mg}(0.089 \mathrm{mmol})$ of $\mathrm{CH}_{3} \mathrm{NO}_{2}$ was added to the reaction mixture at $-20^{\circ} \mathrm{C}$, and $0.19 \mathrm{mmol}$ of $\mathrm{HB}, 0.070 \mathrm{mmol}$ of $1,0.064$ mmol of 3 , and $0.030 \mathrm{mmol}$ of 2 were quantified by ${ }^{1} \mathrm{H}$ NMR at room temperature. After removal of undissolved TCNE $(6.7 \mathrm{mg}$, $0.052 \mathrm{mmol})$, column chromatography yielded $11 \mathrm{mg}(0.052 \mathrm{mmol})$ of 1 and $18 \mathrm{mg}$ of a mixture of 2 and 3 (2.1:1.0 by ${ }^{1} \mathrm{H}$ NMR). The growth of products during the photoreaction was determined using a 1-cm NMR tube charged with the slurry solution of $30 \mathrm{mg}(0.33$ $\mathrm{mmol})$ of $\mathrm{HB}$ with $43 \mathrm{mg}(0.33 \mathrm{mmol})$ of TCNE in $2 \mathrm{ml}$ of $\mathrm{CDCl}_{3}$. Progress of the photoreaction at $0^{\circ} \mathrm{C}(>425 \mathrm{~nm})$ was followed by ${ }^{1} \mathrm{H}$ NMR using $0.27 \mathrm{mmol}$ of $\mathrm{CH}_{3} \mathrm{NO}_{2}$. The amounts of $\mathrm{HB}$ and 1 after $2 \mathrm{~h}, 3 \mathrm{~h}, 4 \mathrm{~h}, 6 \mathrm{~h}$, and $8 \mathrm{~h}$ were as follows; time, mmol $\mathrm{HB}$, mmol 1: $0 \mathrm{~h}, 0.33,0 ; 2 \mathrm{~h}, 0.10,0.017 ; 3 \mathrm{~h}, 0.059,0.027 ; 4 \mathrm{~h}, 0.053$, $0.032 ; 6 \mathrm{~h}, 0.050,0.041 ; 8 \mathrm{~h}, 0.031,0.052$; as presented in Figure 4. Photoreaction of the slurry solution of $69 \mathrm{mg}$ of $\mathrm{HB}(0.75 \mathrm{mmol})$ with $18 \mathrm{mg}$ of TCNE $(0.14 \mathrm{mmol})$ in hexane was carried at $0-5^{\circ} \mathrm{C}$ with a Pyrex cutoff filter $(\lambda>315 \mathrm{~nm})$. Due to weak absorbance at the low energy tails $(300-600 \mathrm{~nm})$, a 10-cm pathlength of cell made of Pyrex with a quartz window was used to increase the absorption of light. After $7 \mathrm{~h}$, the volatile material was evaporated in vacuo. The yellow residue was quantified by ' $\mathrm{H}-\mathrm{NMR}$ analysis to yield $1(0.023 \mathrm{mmol}, 16 \%), 2(0.021 \mathrm{mmol}, 15 \%)$ and $3(0.23$ mmol, $16 \%$ ).

\section{Identification of Photoproduct.s}

Tricyclo[4.3.0.0.7.7non-3-ene-8,8,9,9-tetracarbonitrile (1): Isolation of 1 from the reaction mixture was possible by column chromatography, and it was recrystallized in a mixture of dichloromethane and hexane. $\mathrm{Mp} 166.5-167.0^{\circ} \mathrm{C}$. $-{ }^{1} \mathrm{H}$ NMR $\left(\mathrm{CDCl}_{3}\right)^{*)}$ : $\delta=1.45\left(\mathrm{ddd}, 6-\mathrm{H}_{n}\right), 2.07\left(\mathrm{dd}, 6-\mathrm{H}_{x}\right), 2.79(\mathrm{~m}, 5-\mathrm{H}), 3.05(\mathrm{~m}, 2-\mathrm{H})$, $3.15(\mathrm{~m}, 1-\mathrm{H}), 3.69(\mathrm{~m}, 7-\mathrm{H}), 5.98(\mathrm{ddd}, 4-\mathrm{H}), 6.45(\mathrm{dd}, 3-\mathrm{H}) ; J_{3,4}=$ 5.0, $J_{3,7}=2.9, J_{4,5}=2.9, J_{4,6 x}=1.0, J_{5,6 x}=4.4, J_{6 x, 6 n}=14.2$, $J_{7,6 x}=6.3 \mathrm{~Hz} .-{ }^{13} \mathrm{C}$ NMR $\left(\mathrm{CDCl}_{3}\right): \delta=27.6(\mathrm{C}-6), 39.1,42.8$, $44.8,49.6,50.9,64.5(\mathrm{C}-1,-2,-5,-9,-7,-8), 118.9,109.7,109.9,110.1$, (4 CN), 126.9 (C-4), $138.7(\mathrm{C}-3) .-$ GC MS: $m / z(\%)=220(8.2)$ $\left[\mathrm{M}^{+}\right], 129(100), 102$ (16), 91 (12), 65 (12), 51 (9.0).

\section{$\mathrm{C}_{13} \mathrm{H}_{8} \mathrm{~N}_{4}(220.2) \quad$ Calcd. C 70.90 H 3.64 N 25.45} Found C 70.79 H 3.66 N 25.39

Tetracyclo [4.3.0.0.0.4. $\left.0^{3.9}\right]$ nonane-7,7,8,8-tetracarbonitrile (3): Cycloadduct 3 was always contaminated with 2 even after repeated column chromatography and recrystallization in various solvents. Trial to isolate 3 from the mixture using either $\mathrm{NOCl}$ or $\mathrm{AgNO}_{3}$ was unsuccessful. Cycloadducts 2 and 3 were stable under those conditions. Using the white solid mixture of 3 and 2 (ca. $25 \%$ contamination of 2 by 'H NMR), structural information was obtained from two-dimensional COSY spectroscopy, ${ }^{13} \mathrm{C}$ NMR, and GC MS. Peak assignments in the ${ }^{1} \mathrm{H}-\mathrm{NMR}$ spectrum were made by using a molecular model based on the result of the coupling pattern from the two-dimensional COSY spectrum. - ${ }^{1} \mathrm{H}$ NMR $\left(\mathrm{CDCl}_{3}\right)^{*)}: \delta=1.86(\mathrm{td}, 2-\mathrm{H}), 2.15(\mathrm{tdd}, 4-\mathrm{H}), 2.52(\mathrm{td}, 3-\mathrm{H}), 2.62$ (dd, 5- $\mathrm{H}_{n}$ ), 2.77 (ddd, 5- $\mathrm{H}_{x}$ ), 3.43 (dddd, 6-H), 3.55 (tt, 1-H), 3.74 (ddd, 9-H); $J_{1,9}=J_{1,6}=6.3, J_{9,6}=0.8, J_{9,3}=3.4, J_{1,2}=J_{1,3}=$ $2.8, J_{6,5 x}=11.2, J_{6,5 n}=3.2, J_{5 n, 5 x}=15.4, J_{5 x, 4}=3.6, J_{2,3}=J_{2,4}=$ $J_{4,3}=4.7 \mathrm{~Hz} .-{ }^{13} \mathrm{C} \mathrm{NMR}\left(\mathrm{CDCl}_{3}\right): \delta=18.6(\mathrm{C}-4), 19.8(\mathrm{C}-3), 25.0$ (C-2), 30.9 (C-5), 33.4, 47.5, 48.6 (C-1, -7, -8), 51.8 (C-6), 55.0 (C-9), $110.5-111.8(4 \mathrm{CN}) .-$ GC MS: $m / z(\%)=220(6.0)\left[\mathrm{M}^{+}\right], 129$ (18), $92(34), 91(100), 77(5.9), 76(7.6), 75(5.9), 66(12), 65(13), 63$ (8.0), 52 (6.3), 51 (12), 50 (8.3).

$X$-ray Crystallography of Cycloadduct $1^{\text {s5) }}$ : A large clear faintly yellowish block having approximate dimensions of $0.70 \times 0.40 \times$ $0.25 \mathrm{~mm}$ was carved away from a very large columnar crystal and mounted on a glass fiber in a random orientation on a Nicolet

*) Subscripts $n$ and $x$ refer to endo and exo, respectively. 
$\mathrm{R} 3 \mathrm{~m} / \mathrm{V}$ automatic diffractometer. The radiation used was Mo- $K_{\alpha}$ monochromatized by a highly ordered graphite crystal. Final cell constants, as well as other information pertinent to data collection and refinement, were: space group: $P 2_{1} / c$ (monoclinic); cell constants: $a=8.353(3), b=9.382(2), c=13.836(5) \AA, \beta=91.61(3)^{\circ}$, $V=1084 \AA^{3}$; empirical formula: $\mathrm{C}_{13} \mathrm{H}_{8} \mathrm{~N}_{4}$; mol. mass: 220.3 ; formula units per cell: $Z=4$; density: $\mathrm{Q}=1.35 \mathrm{~g} \mathrm{~cm}^{-3}$; absorption coefficient: $\mu=0.80 \mathrm{~cm}^{-1}$; radiation $\left(\mathrm{Mo}-K_{\mathrm{x}}\right.$ ): $\lambda=0.71073 \AA$; collection range: $4^{\circ}<2 \Theta<55^{\circ}$; scan width: $\Delta \Theta=1.4+\left(K_{\alpha_{2}}-\right.$ $K_{\alpha_{1}}{ }^{\circ}$; scan speed range: 2.0 to $15.0^{\circ} \mathrm{min}^{-1}$; total data collected: 2800; independent data, $I>3 \sigma(I): 1768$; total of variables: 179; $R=\Sigma|| F_{0}|-| F_{\mathrm{c}}|| \Sigma\left|F_{\mathrm{o}}\right|: 0.057 ; R_{w}=\left[\Sigma w\left(\left|F_{0}\right|-\left|F_{\mathrm{c}}\right|\right)^{2} /\right.$ $\left.\Sigma w\left|F_{0}\right|^{2}\right]^{1 / 2}: 0.041$; weights: $w=\sigma(F)^{-2}$. The Laue symmetry was determined to be $2 / \mathrm{m}$, and from the systematic absences noted the space group was shown unambiguously to be $P 2_{1} / c$. Intensities were measured using the $\omega$ scan technique, with the scan rate depending on the count obtained in rapid prescans of each reflection. Two standard reflections were monitored after every two hours or every 100 data collected, and these showed no significant decay. In reducing the data, Lorentz and polarization corrections were applied, however, no correction for absorption was made due to the small absorption coefficient. The structure solution was obtaincd from TREF using the SHELXTL PLUS direct methods, yielding coordinates for all but one of the non-hydrogen atoms in the asymmetric unit, which consists of one complete molecule. The usual sequence of isotropic and anisotropic refinement was followed, after which all hydrogen atoms were entered in ideal calculated positions and allowed to refine independently. A single variable isotropic thermal parameter was assigned to all of the hydrogen atoms. After all shift/ esd ratios were less than 0.1 , convergence was reached at the agreement factors listed above. No unusually high correlations were noted between any of the variables in the last cycle of full-matrix least squares refinement, and the final difference density map showed no peaks larger than $0.30 \mathrm{e} / \AA^{3}$. All calculations were made using Nicolet's SHELXTL PLUS (1987) series of crystallographic programs. Atomic coordinates $\left(\times 10^{3}\right)$ and equivalent isotropic displacement parameters $\left(\times 10^{3}\right)\left[\AA^{2}\right]$ are listed in Table 4 . Selected bond lengths $[\AA]$ and bond angles $\left[{ }^{\circ}\right]$ are listed in Table 5 .

Thermal Reaction of Homobenzvalence with TCNE: The orange solution of $\mathrm{HB}(0.43 \mathrm{mmol})$ with TCNE $(0.32 \mathrm{mmol})$ in $5 \mathrm{ml}$ of

Table 4. Atomic coordinates $\left(\times 10^{4}\right)$ and equivalent isotropic displacement parameters $\left(\times 10^{3}\right)\left[\AA^{2}\right]$ for cycloadduct 1 ; equivalent isotropic $U$ defined as onc third of the trace of the orthogonalized $U_{i i}$ tensor

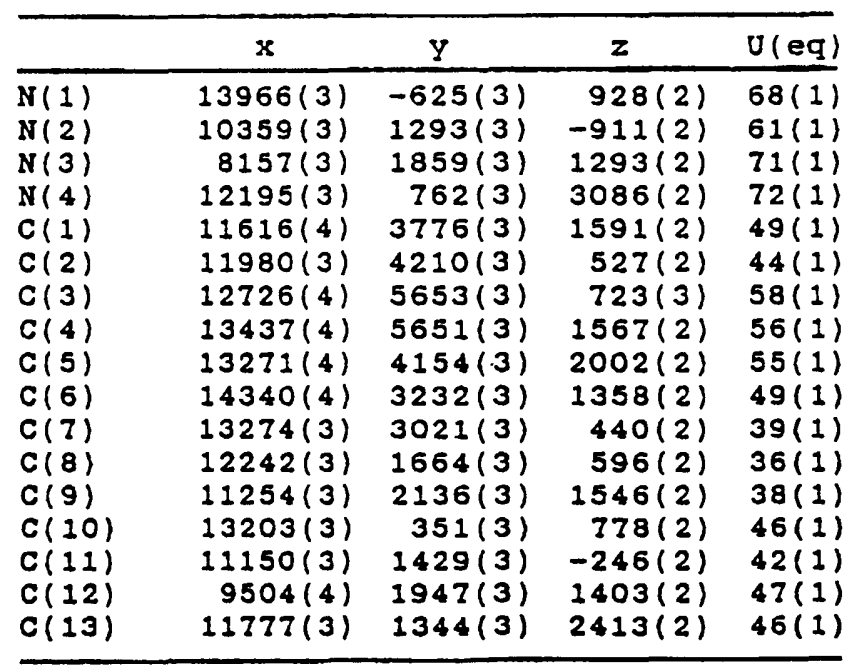

Table 5. Selected bond lengths $[\AA]$ and bond angles $\left[{ }^{\circ}\right]$ for the cycloadduct $i$

\begin{tabular}{lrlll}
\hline$C(1)-C(5)$ & $1.522(4)$ & $C(1)-C(2)$ & $1.566(4)$ \\
$C(2)-C(7)$ & $1.560(4)$ & $C(1)-C(9)$ & $1.569(4)$ \\
$C(3)-C(4)$ & $1.295(4)$ & $C(2)-C(3)$ & $1.512(4)$ \\
$C(4)-C(5)$ & $1.536(4)$ & $C(6)-C(7)$ & $1.543(4)$ \\
$C(5)-C(6)$ & $1.545(4)$ & $C(7)-C(8)$ & $1.556(4)$ \\
$C(8)-C(9)$ & $1.633(3)$ & $C(9)-C(12)$ & $1.481(4)$ \\
$C(8)-C(10)$ & $1.488(4)$ & $C(12)-N(3)$ & $1.134(3)$ \\
& & & & \\
$C(5)-C(1)-C(2)$ & $95.3(2)$ & $C(9)-C(1)-C(5)$ & $114.5(2)$ \\
$C(9)-C(1)-C(2)$ & $105.1(2)$ & $C(3)-C(2)-C(1)$ & $98.9(2)$ \\
$C(5)-C(4)-C(3)$ & $108.1(3)$ & $C(7)-C(2)-C(1)$ & $92.3(2)$ \\
$C(4)-C(5)-C(1)$ & $99.1(3)$ & $C(7)-C(2)-C(3)$ & 111.8 (2) \\
$C(6)-C(5)-C(4)$ & $103.1(3)$ & $C(4)-C(3)-C(2)$ & $109.6(3)$ \\
$C(6)-C(7)-C(2)$ & $103.3(2)$ & $C(6)-C(5)-C(1)$ & 100.8 (2) \\
$C(8)-C(7)-C(6)$ & $107.5(2)$ & $C(7)-C(6)-C(5)$ & $102.5(2)$ \\
$C(9)-C(8)-C(7)$ & $100.6(2)$ & $C(8)-C(7)-C(2)$ & 100.8 (2) \\
$C(8)-C(9)-C(1)$ & $101.3(2)$ & & \\
\hline
\end{tabular}

$\mathrm{CH}_{3} \mathrm{CN}$ was stirred at room temperature under an argon atmosphere. After $15 \mathrm{~h}$, the resultant dark yellow brown solution was concentrated in vacuo. The crude reaction mixture was resolved into its components by column chromatography on neutral alumina (Aldrich). Elution with a mixture of hexane and ether $(1: 1$; $\mathrm{v} / \mathrm{v})$ yielded cycloadduct $5(3.5 \mathrm{mg} ; 0.016 \mathrm{mmol})$ as a colorless solid. The colorless mixture of cycloadducts 4 and $2(18 \mathrm{mg} ; 4.4: 1.0$ by ${ }^{1} \mathrm{H}$-NMR integration) followed. Cycloadduct 4 was isolated as pure colorless crystals by repeated crystallization with $\mathrm{CCl}_{4}$. The thermal reactions in the other solvents were performed in the dark at room temperature under an argon atmosphere. The yellow solution of $0.42 \mathrm{mmol}$ of HB with $0.10 \mathrm{mmol}$ of TCNE in $5 \mathrm{ml}$ of THF was stirred for 7 days. The dark yellow solution was analyzed by ${ }^{1} \mathrm{H}$ NMR using $\mathrm{CH}_{3} \mathrm{NO}_{2}$ as an internal standard. The reddish yellow solution of $1.46 \mathrm{mmol}$ of homobenzvalene with $0.46 \mathrm{mmol}$ of TCNE in $8 \mathrm{ml}$ of dichloromethane initially yielded a yellow solution and then became darker. After 7 days, the solvent was removed to give $92 \mathrm{mg}$ of a light brown residue. Cycloadduct $5(13 \mathrm{mg}, 13 \%)$ was isolated from the initial chromatographic fraction with a mixture of hexane and ether $(1: 1 ; \mathrm{v} / \mathrm{v})$. The mixture of 4 and $2(47 \mathrm{mg})$ followed, and their amounts were quantified by ${ }^{1} \mathrm{H}-\mathrm{NMR}$ analysis to yield $4(0.14$ mmol, $30 \%)$ and $2(0.71 \mathrm{mmol}, 15 \%)$. The red-orange solution of $0.92 \mathrm{mmol}$ of homobenzvalene with $0.33 \mathrm{mmol}$ of TCNE in $6 \mathrm{ml}$ of chloroform was stirred for 3 days to give a dark yellow-brown solution containing a small amount of undissolved TCNE. TCNE ( $6.4 \mathrm{mg}, 0.05 \mathrm{mmol}$ ) was removed by filtration and the solution concentrated in vacuo. The brown residue was analyzed by ${ }^{1} \mathrm{H}$ NMR spectroscopy to give $0.011 \mathrm{mmol}$ of $4,0.013 \mathrm{mmol}$ of 5 , and $0.05 \mathrm{mmol}$ of 2 using $\mathrm{CH}_{3} \mathrm{NO}_{2}$ as an internal standard. From a large-scale reaction and repeated column chromatography, cycloadducts 4,5 , and 2 were isolated and used as authentic samples.

Tricyclo[3.3.1. $0^{2.8}$ ]non-6-ene-3,3,4,4-tetracarbonitrile (4): $\mathrm{Mp}$ $182-184^{\circ} \mathrm{C}$ (ref. $\left.{ }^{11} 181^{\circ} \mathrm{C}\right) .-{ }^{1} \mathrm{H} \mathrm{NMR}\left(\mathrm{CDCl}_{3}\right): \delta=1.70(9-\mathrm{H}$, unti), $2.14(8-\mathrm{H}), 2.16(1-\mathrm{H}), 2.54(2-\mathrm{H}), 2.70(9-\mathrm{H}, s y n), 3.13(5-\mathrm{H})$, 6.14 (6-H), $6.45(7-\mathrm{H}) .-$ GC MS: $m / z(\%)=220(13)\left[\mathrm{M}^{+}\right], 129$ (16), 92 (100), 91 (90), 77 (12), 76 (12), 65 (13), 64 (11), 63 (14).

3- $\left(2^{\prime}, 4^{\prime}-\right.$ Cyclohexadien- $\left.t^{\prime}-y l\right)-1,1,2,2-$ cyclopropanetetracarbonitrile $^{11)}(5)$ : 'H NMR $\left(\mathrm{CD}_{3} \mathrm{COCD}_{3}\right): \delta=2.31\left(1^{\prime}-\mathrm{H}\right), 2.60,2.81\left(6^{\prime}-\right.$ 
$\left.\mathrm{H}_{2}\right), 3.80(3-\mathrm{H}), 5.97\left(5^{\prime}-\mathrm{H}\right), 6.02\left(2^{\prime}-\mathrm{H}\right), 6.08\left(4^{\prime}-\mathrm{H}\right), 6.21\left(3^{\prime}-\mathrm{H}\right)$. GC MS: $m / z(\%)=220(14)\left[\mathrm{M}^{+}\right], 155(16), 92(30), 91(38), 79$ (73), 78 (100), 77 (54), 76 (14), 65 (13), 63 (12), 52 (26), 51 (44), 50 (29).

Tricyclo[3.2.2.0.2.4 Jnon-8-ene-6,6,7,7-tetracarbonitrile ${ }^{17)}$ (2): ${ }^{\prime} \mathrm{H}$ NMR $\left(\mathrm{CDCl}_{3}\right)^{*)}: \delta=0.35\left(3-\mathrm{H}_{n}\right), 0.73\left(3-\mathrm{H}_{x}\right), 1.70(2-, 4-\mathrm{H}), 3.90$ (1-, 5-H), $6.24(8-, 9-\mathrm{H}) .-{ }^{13} \mathrm{C} \mathrm{NMR}\left(\mathrm{CDCl}_{3}\right): \delta=5.07$ (d, $J_{\mathrm{CH}}=$ $175 \mathrm{~Hz}, \mathrm{C}-2,-4), 5.11\left(\mathrm{t}, J_{\mathrm{CH}}=165 \mathrm{~Hz}, \mathrm{C}-3\right), 42.0\left(\mathrm{~d}, J_{\mathrm{CH}}=170\right.$ $\mathrm{Hz}, \mathrm{C}-1,-5), 42.8$ (s, C-6, -7), 111.1, $111.8(4 \mathrm{CN}), 129.0$ (d, $J_{\mathrm{CH}}=$ $178 \mathrm{~Hz}, \mathrm{C}-8,-9) .-$ IR $(\mathrm{KBr}): \tilde{v}=3089,3040,3019,2970,2253$ $(C \equiv N), 1699,1373,1267,1104,1051,1038,908,847,819,778,737$, $627,599 \mathrm{~cm}^{-1}$.

*) Subscripts $n$ and $x$ refer to endo and exo, respectively.

\section{CAS Registry Numbers}

1: $126135-07-7$ / 2: 62249-53-0 / 3: 126135-08-8 / 4: 96865-98-4 / 5: $23767-79-5$ / HB: 35618-58-7 / TCNE: 670-54-2 / HB - TCNE: $126156-03-4$

"R. E. Merrifield, W. D. Phillips, J. Am. Chem. Soc. 80 (1958) 2778.

2) P. M. Rentzepis, M. Sc. Thesis, Syracuse University, State University College of Forestry, 1959.

${ }^{3)}$ For a summary, see: ${ }^{3 a)}$ E. Ciganek, W. J. Linn, O. W. Webster in The Chemistry of the Cyano Group ( $\mathrm{Z}$. Rappoport, Ed.), p. $449 \mathrm{ff}$, Interscience, New York 1970. - ${ }^{36)}$ D. Brown, R. C. Cookson, Tetrahedron 21 (1965) 1977.

4) R. S. Mulliken, J. Am. Chem. Soc. 72 (1950) 600.

5) R. S. Mulliken, W. B. Person Molecular Complexes, Wiley, New York 1969.

6) S. Fukuzumi, J. K. Kochi, Tetrahedron 38 (1982) 1035.

7) Y. Takahashi, J. K. Kochi, Chem. Ber. 121 (1988) 253.

8) 8ai R. Huisgen, H. Seidl, Tetrahedron Lett. (1964) 3381. - ${ }^{\text {sh) }} \mathrm{R}$. Huisgen, F. Mietsch, Angew. Chem. 76 (1964) 36; Angew. Chem. Int. Ed. Engl. 3 (1964) 83.

9) K. H. Grellmann, J. Palmowski, G. Quinkert, Angew. Chem. 83 (1971) 209; Angew. Chem. Int. Ed. Engl. 10 (1971) 196.

10) J. M. Masnovi, unpublished results.

11) M. Christl, R. Lang, C. Herzog, R. Stangl, K. Peters, E.-M. Peters, H. G. von Schnering, Angew. Chem. 97 (1985) 595; Angew. Chem. Int. Ed. Engl. 24 (1985) 611.

${ }^{12)} \mathrm{M}$. Christl, private communication, October 22, 1987.

13) H. A. Benesi, J. H. Hildebrand, J. Am. Chem. Soc. 71 (1949) 2703.

14) W. B. Person, J. Am. Chem. Soc. 87 (1965) 167.

${ }^{15)}$ R. F. Foster Organic Charge-Transfer Complexes, Academic, New York 1969.

16) M. Tamres in Molecular Complexes (R. Foster, Ed.), p. $49 \mathrm{ff}$, Elek Science, New York 1973.

17) 17a) G. H. Wahl, Jr., J. Org. Chem. 33 (1968) 2158. - ${ }^{17 b) ~ N . ~ W . ~}$ Jordan, I. W. Elliott, J. Org. Chem. 27 (1962) 1445.

${ }^{18)}$ R. Lang, Dissertation, Univ. Würzburg, 1982.

19) R. Lang, C. Herzog, R. Stangl, E. Brunn, M. Braun, M. Christl, E.-M. Peters, K. Peters, H. G. von Schnering, Chem. Ber. 123 (1990) 1193, preceding paper.

20) A. R. Browne, L. A. Paquette, J. Org. Chem. 43 (1978) 4522. See also: M. Christl, B. Mattauch, Chem. Ber. 118 (1985) 4203.

${ }^{21)}$ D. A. Dixon, J. S. Miller, J. Am. Chem. Soc. 109 (1987) 3656.

${ }^{22)}$ Of the potassium salt $\mathrm{K}^{+}$TCNE - prepared according to ref. ${ }^{23)}$.

${ }^{23)}$ O. W. Webster, W. Mahler, R. E. Benson, J. Am. Chem. Soc. 84 (1962) 3678.

24) See: C. Reichardt, Solvent Effects in Organic Chemistry, Verlag Chemie, Weinheim, New York 1979.

25) For a similar study of solvent effects on product distribution see ref. ${ }^{199}$.

${ }^{26)}$ E. F. Hilinski, J. M. Masnovi, J. K. Kochi, P. M. Rentzepis, J. Am. Chem. Soc. 106 (1984) 8071.

${ }^{27}$ See also: ${ }^{27 a)}$ N. Mataga, Pure Appl. Chem. 56 (1984) 1255. 27b) S. Nagakura in Excited States (E. C. Lim, Ed.) vol. 2, Aca- demic, New York 1975. - ${ }^{27 c)}$ R. L. Ward, J. Chem. Phys. 39 (1963) 852. - 27d) D. F. Ilten, M. Calvin, J. Chem. Phys. 42 (1965) 3760. - 27e) K. Weiss, Y. P. Pilette, J. Phys. Chem. 75 (1971) 3805. - ${ }^{270}$ H. Masuhara, M. Shimada, N. Tsujino, N. Mataga, Bull. Chem. Soc. Jpn. 44 (1971) 3310.

${ }^{28)}$ R. S. Mulliken, J. Am. Chem. Soc. 74 (1952) 811.

29) J. M. Masnovi, E. G. Hilinski, P. M. Rentzepis, J. K. Kochi, J. Am. Chem. Soc. 108 (1986) 1126.

30) 30a) J. M. Wallis, J. K. Kochi, J. Am. Chem. Soc. 110 (1988) 8207. - ${ }^{306)}$ Y. Takahashi, S. Sankararaman, J. K. Kochi, J. Am. Chem. Soc. 111 (1989) 2954; see also ref. ${ }^{39}$.

31) For TCNE, the electron affinity $E A=2.3 \mathrm{eV}$ and the reduction potential $E_{\text {red }}^{i}=0.24 \mathrm{~V}$ versus SCE; see: ${ }^{31 a)} \mathrm{O}$. W. Webster W. Mahler, R. E. Benson, J. Am. Chem. Soc. 84 (1962) 3678. - ${ }^{316)}$ R. O. Loutfy, C. K. Hsiao, B. S. Ong, B. Keoshkerian, Can. J. Chem. 62 (1984) 1877. - ${ }^{311}$ ' S. Chowdhury, P. Kebarle, J. Am. Chem. Soc. 108 (1986) 5453.

32) For homobenzvalene, the vertical ionization potential $I P=$ $8.82 \mathrm{eV}$ and the oxidation potential $E_{\text {ox }} \approx 1.8 \mathrm{~V}$ versus SCE [estimated from the correlation by P. G. Gassmann, K. D. Olson, L. Walter, R. Yamaguchi, J. Am. Chem. Soc. 103 (1981) 4997]. For the estimate of $k_{\text {bet }}$, see ref. ${ }^{33,386)}$.

33) See: G. Jones, II in Photoinduced Electron Transfer (M. A. Fox, M. Chanon, Eds.) part A, p. $245 \mathrm{ff}$., Elsevier, Amsterdam 1988.

34) 344) R. C. Dunbar, R. Klein, J. Am. Chem. Soc. 99 (1977) 3744. 34b) G. Jones, II, W. G. Becker, Chem. Phys. Lett. 85 (1982) 271. - ${ }^{34 c}$ G. Jones, II, W. G. Becker, J. Am. Chem. Soc. 105 (1983) 1276. - ${ }^{34 d)}$ N. J. Peacock, G. B. Schuster, J. Am. Chem. Soc. 105 (1983) 3632.

35) 35a) T. Bally, D. Hasselmann, K. Loosen, Helv. Chim. Acta 68 (1985) 345 . - ${ }^{35 b}$ H. D. Roth, C. J. Abelt, J. Am. Chem. Soc. 108 (1986) 2013. - ${ }^{35 c)}$ T. Miyashi, M. Kamata, T. Mukai, J. Am. Chem. Soc. 109 (1987) 2780. - 350) R. A. W. Johnstone, S. D. Ward, J. Chem. Soc. C, 1968, 1805. - ${ }^{36 c)}$ M. J. Bishop, I. Fleming, J. Chem. Soc. C, 1969, 1712.

(36) In the quenching of chloranil by homobenzvalene, CIDNP was observed only in a product and not in the reactant ${ }^{366)}$. Since these CIDNP effects are identical to those generated in the product cation radicals under comparable conditions ${ }^{3(6)}$, the rearrangement of $\mathrm{HB}^{+}$must be faster than geminate recombination occurring on the time scale of $1-10 \mathrm{~ns}$. $-{ }^{366)} \mathrm{C}$. J. Abelt, H. D. Roth, M. L. M. Schilling, J. Am. Chem. Soc. 107 (1985) 4148. ${ }_{36 c)}$ H. D. Roth, M. L. M. Schilling, Can. J. Chem. 61 (1983) 1027.

37) The transformations involve $1 \pm$ by (i) the $[1,2]$ Wagner-Meerwein shift of bond $a$ and cleavage of bond $b, 2 t$ by (ii) cleavages of bonds $a$ and $c$, and $3+$ by (iii) $[1,2]$ Wagner-Meerwein shift of bond a.

38) J. M. Masnovi, J. K. Kochi, J. Am. Chem. Soc. 107 (1985) 7880. See also: S. Sankararaman, S. Perrier, J. K. Kochi, J. Am. Chem. Soc. 111 (1989) 6448.

39) T. M. Bockman, J. K. Kochi, J. Am. Chem. Soc. 111 (1989) 4669.

40) The persistence of TCNE - for several hours indicates that it exists in acetonitrile solution as the SSIP ${ }^{38)}$.

41) J. Santamaria in Photoinduced Electron Transfer cited in ref. ${ }^{33)}$, part B, p. $483 \mathrm{ff}$.

42) T. J. Katz, N. Acton, J. Am. Chem. Soc. 95 (1973) 2738

43) Whether such occurs directly by the collisional activation of $\mathrm{HB}$ and TCNE or via an intermediate complex is a moot point and is therefore not addressed here. For a discussion see ref. ${ }^{6,44)}$.

44) R. Sustmann, M. Dern, R. Kasten, W. Sicking, Chem. Ber. 120 (1987) 1315.

45) See: E. S. Lewis in Investigation of Rates and Mechanisms of Reactions (A. Weissberger, Ed.) part I, chapt. 1, Wiley, New York 1961.

46) The transformations involve $4 \pm$ by (iv) cleavage of bond a and $5 t$ by (v) cleavage of bonds $a$ and $b$.

${ }^{47)}$ For the marked solvent effects in polar cycloadditions, see: $\mathbf{R}$. Huisgen, Pure Appl. Chem. 52 (1980) 2283.

48) P. Bischof, R. Gleiter, R. T. Taylor, A. R. Browne, L. A. Paquette, J. Org. Chem. 43 (1978) 2391.

19) R. Gleiter, Top. Curr. Chem. 86 (1979) 197.

50) 50a) M. Christl, G. Freitag, G. Brüntrup, Chem. Ber. 111 (1978) 2320. - s0b) C. Herzog R. Lang, D. Brückner, P. Kemmer, M. Christl, Chem. Ber. 119 (1986) 3027. - 50c) M. Christl, C. Herzog, D. Brückner, R. Lang, Chem. Ber. 119 (1986) 141.

51) For structures of TCNE complexes, see: J. M. Masnovi, E. F. Hilinski, P. M. Rentzepis, J. K. Kochi, J. Phys. Chem. 89 (1985) 5387. 
52) 52a) P. Bischof, R. Gleiter, E. Müller, Tetrahedron 32 (1976) 2769. - 526) P. J. Harman, J. E. Kent, T. H. Gan, J. B. Peel, G. D. Willet, J. Am. Chem. Soc. 99 (1977) 943.

s3) M. Christl, E. Brunn, F. Lanzendörfer, J. Am. Chem. Soc. 106 (1984) 373.

54) A. Bax, R. Freeman, G. Morris, J. Magn. Reson. 42 (1981) 164.
53) Further details of the crystal structure investigation are available on request from the Fachinformationszentrum Karlsruhe, Gesellschaft für wissenschaftlich-technische Information $\mathbf{m b H}$ D-7514 Eggenstein-Leopoldshafen 2, F.R.G., on quoting the depository number CSD-54346, the names of the authors, and the journal citation.

(C) VCH Verlagsgesellschaft mbH, D-6940 Weinheim, 1990 - Printed in the Federal Republic of Germany.

Verantwortlich für den Inhalt: Prof. Dr. Heinrich Nöth, München (Teil A), Prof. Dr. Henning Hopf, Braunschweig (Teil B). Redaktion: Dr. Robert Temme, Weinheim. VCH Verlagsgesellschaft mbH (Geschäftsfuhrer: Hans Dirk Köhler), Pappelallee 3, Postfach 101161, D-6940 Weinheim.

Anzeigenleitung: R. J. Roth, Weinheim.

Die Wiedergabe von Gebrauchsnamen, Handelsnamen, Warenbezeichnungen und dgl in dieser Zeitschrift berechtigt nicht zu der Annahme, daß solche Namen ohne weiteres von jedermann benutzt werden dürfen. Vielmehr handelt es sich häufig um gesetzlich geschützte eingetragene Warenzeichen, auch wenn sie nicht als solche gekennzeichnet sind

Alle Rechte, insbesondere die der Ubersetzung in andere Sprachen, vorbehalten. Kein Teil dieser Zeitschrift darf ohne schriftliche Genehmigung des Verlages in irgendeiner Form durch Photokopie, Mikrofilm oder irgendein anderes Verfahren - reproduziert oder in eine von Maschinen, insbesondere von Datenverarbeitungsmaschinen verwendbare Sprache übertragen oder übersetzt werden. - All rights reserved (including those of translation into other languages). No part of this issue may be reproduced in any form - by photoprint, microfilm, or any other means - nor transmitted or translated into a machine language without the permission in writing of the publishers. - Von einzelnen Beiträgen oder Teilen von ihnen dürfen nur einzelne Vervielfältigungsstücke für den persönlichen oder sonstigen eigenen Gebrauch hergestellt werden. Die Weitergabe von Vervielfältigungen, gleichgültig zu welchem Zweck sie hergestellt werden, ist eine Urheberrechtsverletzung. - Der Inhalt dieses Heftes wurde sorgfältig erarbeitet. Dennoch übernehmen Autoren, Herausgeber, Redaktion und Verlag fur die Richtigkeit von Angaben, Hinweisen und Ratschlagen sowie fur eventuelle Druckethler keine Haftung. - This journal was carefully produced in all its parts. Nevertheless, authors, edicors and publisher do not warrant the information con

Valid for users in the USA: The appearance of the code at the bottom of the first page of an article in this journal (serial) indicates the copyright owner's consent that copies of the article may be made for personal or internal use, or for the personal or internal use of specific clients. This consent is given on the condition, however, that the copier pay the stated percopy fee through the Copyright Clearance Center, Inc., for copying beyond that permitted by Sections 107 or 108 of the U.S. Copyright Law. This consent does not extend to other kinds of copying, such as copying for general distribution, for advertising or promotional purposes, for creating new collective work, or for resale. For copying from back volume of this journal see "Permissions to Photo-Copy: Publisher's Fee List" of the CCC

In der Zeitschrift werden keine Rezensionen veröffentlicht; zur Besprechung eingehende Bücher werden nicht zurück gesandt.

Satz und Druck: Krebs-Gehlen Druckerei, Hemsbach/Bergstra Be.

Printed on acid-free paper / Gedruckt auf săurefreiem Papie 